UDC 613.95: 616-006.44: 614.876

DOI: $10.21668 /$ health.risk/2016.4.03.eng

\title{
HEMOBLASTOSES IN OFFSPRING OF RADIATION-HAZARDOUS INDUSTRIES WORKERS
}

\author{
S.F. Sosnina, N.R. Kabirova, M.E. Sokolnikov, P.V. Okatenko \\ Southern Urals Biophysics Institute, 19 Ozerskoe shosse, Ozersk, 454780, Russian Federation
}

Malignant tumors of hematopoietic and lymphoid tissues in children have polyetiologic nature, including some contribution of parents' exposure to radiation. The causal relationships between parental chronic preconceptive external gamma-irradiation and hematological malignancies in their children have been studied. Retrospective epidemiological study based on a "nested case-control approach" using matching method was carried out in the cohort of Ozyorsk pediatric population. "Case” is defined as a child under 15 years old with diagnosed hemoblastosis. The "control" group is the one without such a diagnosis. The controls were selected from the same Ozyorsk children's cohort by matching cases on sex, birth year and parents' age at children's birth. Subgroups of children who are offspring of those occupationally exposed are distinguished. Calculation odds ratio (OR) with $95 \%$ confidence interval (CI) is performed. There were 51 children under 15 years age diagnosed with hemoblastosis in Ozyorsk within 1949-2009. The control group included 197 health children. $29.4 \%$ (15 children) in the study group were offspring of people who had accumulated doses of preconceptive exposure, whereas in the control group the indicator is $43.1 \%$ (85 children). The total doses of external gamma radiation on the parent's gonad varied widely (2.1-3397.3 mGy in the study group and 0.5-2899.3 $\mathrm{mGy}$ in the control group). The average age of leukemia contraction was 6 years without regard to sex. Acute leukemia was a major contributor to the hemoblastosis structure (66.7 \% of all cases). Analysis of the data showed no statistical relationship between preconceptional prolonged external gamma-radiation exposure in parents and oncohematological pathology in their offspring. OR indicator amounted 0.55 (0.28-1.07), among boys - 0.48 (0.19-1.22), among girls - 0.64 (0.25-1.65).

Key words: retrospective study, hematological malignancies, children, offspring of workers, preconceptive exposure, IG "Mayak", odds ratio.

Hemoblastosis ranks first in the structure of pediatric cancer. According to the International Consortium for childhood leukemia [23], to date, there have been identified numerous potential risk factors for oncohematological diseases in children, including immunological disorders of innate and adaptive nature, polymorphism of histocompatibility system, effect of various environmental factors, including chemical mutagens and ionizing radiation.

Crump C. et al [21] colligate higher risk of acute leukemia with a high fetal growth rate. Chang J.S. and Tsai C.R. [19] consider infectious etiology (viral and bacterial infections), as a trigger factor for neoplasm. The role of prenatal and postnatal exposure to electromagnetic fields in the development of acute lymphoblastic leukemia in children is defined by Tabrici M. and Hosseini S. [22] in their work. Puumala S. et al [14] reviewing 180 articles devoted to the etiology of leukemia, emphasis on the genetic and epigenetic mechanisms of leukemia development. Analyzing molecular mechanisms of leukocytogenesis, Domninsky D.A. [3] believes that transloca-

(C) Sosnina S.F., Kabirova N.R., Sokolnikov M.E., Okatenko P.V., 2016

Svetlana F. Sosnina - Candidate of Medicine, Researcher, Laboratory of Epidemiology long-term effects of radiation exposure in staff and public (e-mail: sosnina@subi.su; tel.: +7 (35130) 76627).

Nailya R. Kabirova - Researcher, Laboratory of Epidemiology long-term effects of radiation exposure in staff and public (e-mail: kabirova@ subi.su; tel.: +7 (35130) 73076).

Mikhail J. Sokol'nikov - Doctor of Medicine, Head of Laboratory of Epidemiology long-term effects of radiation exposure in staff and public (e-mail: sokolnikov@ subi.su; tel.: +7 (35130) 71652).

Pavel V. Okatenko - team leader of computer and software group, Laboratory of Epidemiology long-term effects of radiation exposure in staff and public (e-mail: okatenko@ subi.su; tel.: +7 (35130) 76903). 
tions determine hemoblastosis phenotype.

Exposure of parents to radiation before conception is considered as one of the potential risks of cancer pathology in offspring. Epidemiological studies on the effects of parental exposure were conducted among the offspring of the atomic bombing victims [20], the Chernobyl Nuclear Power Plant (CNPP) accident responders [4], the patients who underwent diagnostic and therapeutic radiation exposure [11], the descendants of professionals [7.9 12], as well as those living near the radiationhazardous sites [16,17].

The trans-generational transmission route of cytogenetic effects, mitochondrial DNA role in cancer process, genetic and epigenetic disorders that contribute to carcinogenesis $[10,13,15]$ are under discussion as plausible scenarios for pathogenesis of hematological malignancies in the offspring of persons exposed to pre-conceptive radiation.

Mixed results of epidemiological and molecular genetic studies do not allow for setting the causal relationship between preconceptive exposure of parents and hemoblastosis in their descendants. On this basis, it is important to study the carcinogenic effects of parents' exposure to radiation in offspring cohort of the workers at PE "Mayak" - the first nuclear company in Russia, which is the main employer in Ozyorsk town.

PE "Mayak", operational since 1948, includes reactor, radiochemical, plutonium processing and a number of auxiliary production units. In technology development period (1948-1958), the staff, $25 \%$ of whom were women, was under sustained exposure to external gamma- and internal alpha-irradiation with incorporated plutonium-239 in large doses.

Objective: To evaluate statistical relationship between pre-conceptive sustained external gamma radiation of the workers at PE "Mayak" and hematological malignancies in their children.

\section{Data and methods}

The study was performed based on several registers put in place and kept with epidemiological laboratory for long-term effects of radiation exposure in personnel and population of Federal State Unitary Enterprise South-Urals Biophysics Institute:

- Cancer-register, including data of 13,867 cancer cases among Ozyorsk population for 1948-2014.

- Pediatric register [8], which consolidates data on 90,835 people born in 1934-2009 in the town of Ozyorsk, or moved to the town at an early age and lived there for at least a year,

- Register of PE "Mayak" personnel [5], including 35,884 people employed during 1948-2014 at the enterprise operations and auxiliary plants, which served as the data source of parents' occupational route.

The study also involved info from the data file of the incident emergency workers in 1957, settlers from the East Urals Radioactive Trace, the liquidators of Chernobyl accident, info details of construction, military units, whose personnel could had been exposed to radiation before conception.

Follow-up parameters of personnel external gamma radiation exposure are provided by the radiation security service of $\mathrm{PE}$ "Mayak" from the Employees' Dosimetry System of Mayak-2008 [1.18]. The doses of gonad external gamma-irradiation were calculated by Monte Carlo method based on showings of personal dosimeters and spatial and energy distribution of photon radiation field at workplace. For plutonium processing personnel, we presented and studied only the doses of external gamma-irradiation.

We used statistical "nested case-control "approach. "Case" is defined as a child under 15 years old diagnosed with hemoblastosis, "control" refers to a child of the same year of birth without given diagnosis. All cases of hemoblastosis in children under the age of 15 in Ozyorsk town in the period from 1949 to 2009 were obtained from the Cancer-register (51 children: 28 boys and 23 girls). Next, using the comparable pairs, every child with hemoblastosis was given 3-4 controls from the Pediatric register matching by sex, year of birth and age of parents at child's birth (197 children with no hemolymphoblastosis diagnosed: 107 boys, 
90 girls). The groups were selected among the whole children population of Ozyorsk that allowed neutralize other eventually-interfering factors, including potential technologic impact on the population due to their inhabitance in proximity to nuclear enterprises. In addition, the period under study was characterized by the same healthcare quality standard and a similar food ration for the organized groups of children.

Upon completion of these two groups formation, according to PE "Mayak" personnel register and Employees' Dosimetry System of Mayak-2008, we established the fact and the dose of parents' pre-conceptive exposure.

Each group is divided into two subgroups: children whose parents had the accumulated doses of pre-conceptive radiation, and children whose parents were not exposed to occupational radiation exposure before conception. As shown in Table 1, the proportion of irradiated parents in the control group was even higher than that of children with hematological malignancies: in the main group $29.4 \%$ (15 children) were born in families whose parents had the accumulated doses of preconceptive exposure; in the group of children without onco-hematological pathology $43.1 \%$ ( 85 children) were the descendants of persons occupationally exposed to radiation prior to conception.

To test the hypothesis on potential effect of parental exposure before conception to hemoblastosis development in the offspring, we calculated odds ratios with $95 \%$ confidence interval.

Table 1

Groups' dimension

\begin{tabular}{|l|c|c|c||c|c|c|c|c|c|}
\hline \multirow{2}{*}{ Group } & \multicolumn{3}{|c|}{$\begin{array}{c}\text { Number of children } \\
\text { in a group }\end{array}$} & \multicolumn{3}{|c|}{ Irradiated parents offspring } & \multicolumn{3}{c|}{ Unexposed parents offspring } \\
\cline { 2 - 11 } & Total & Boys & Girls & Total & Boys & Girls & Total & Boys & Girls \\
\hline «Cases» & 51 & 28 & 23 & 15 & 7 & 8 & 36 & 21 & 15 \\
\hline «Controls» & 197 & 107 & 90 & 85 & 44 & 41 & 112 & 63 & 49 \\
\hline
\end{tabular}

Results and discussion. According to the Cancer Register data, the first time child hemoblastosis in Ozyorsk was registered in June 1955, diagnosed with acute myeloid leukemia in the three -years old infant whose parents prior to conception were not in occupational contact with the sources of ionizing radiation. For the entire observation period (1949-2009), the boys among all children with onco-hematological pathology (51 children) became ill more often: 28 persons (54.9\%). Sex ratio 1.22: 1, with predominance of boyspatients, falls into line with the published data [6.23]. The largest number of hematological malignancies was diagnosed for the periods 1961- 1970 (12 cases) and 1980-1989 (11 cases). Leukemia structure among the total chil dren population of Ozyorsk for a 60-years followup is presented in Figure 1.

Among the malignant neoplasms of lymphatic and hematopoietic tissues, the most common one was acute leukemia, which accounts for $66.7 \%$ (34 cases). In the structure of acute leukemia, the acute lymphoblastic leukemia dominated $(58.8 \%)$, which is also a characteristic of pediatric onco-hematology [23]. The specific contribution of myeloid leukemia was $17.7 \%$ of all leukemia cases.

Leukemia ranking by sex is shown in Fig. 2. Both among boys and girls, the acute lymphoblastic leukemia ranked first, whose share made more than $39 \%$ with no significant differences by gender $(39.3 \%$ boys and $39.1 \%$ girls). 


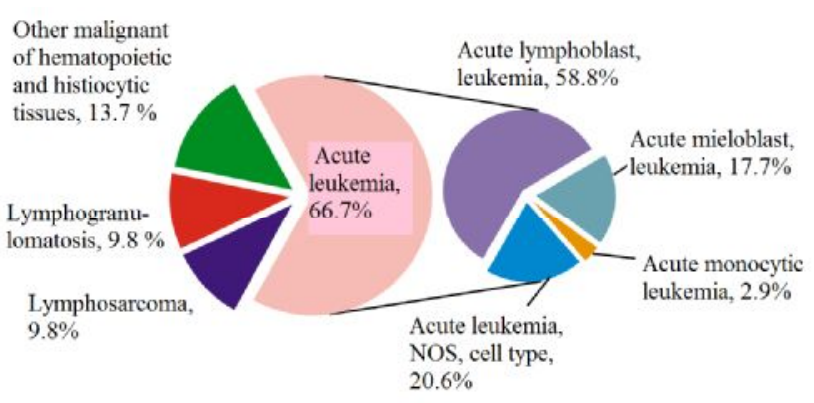

Fig.1. Leukemia structure among children population of Ozyorsk (\%)

Gender differences in the structure of children's hemolymphoblastosis were identified only for acute myeloid leukemia, ranking second in girls (21.7\%), while the contribution of this pathology among boys amounted to $3.6 \%$ only. Lymphogranulomatosis occurred with equal frequency among children of both sexes: $14.3 \%$ boys and $13.1 \%$ girls. A similar percentage was noted for the subclass "Other malignant neoplasms of lymphoid and histiocytic tissues", including histiocytic lymphoma, malignant histiocytosis. Acute monocytic leukemia was the least often hematologic malig-

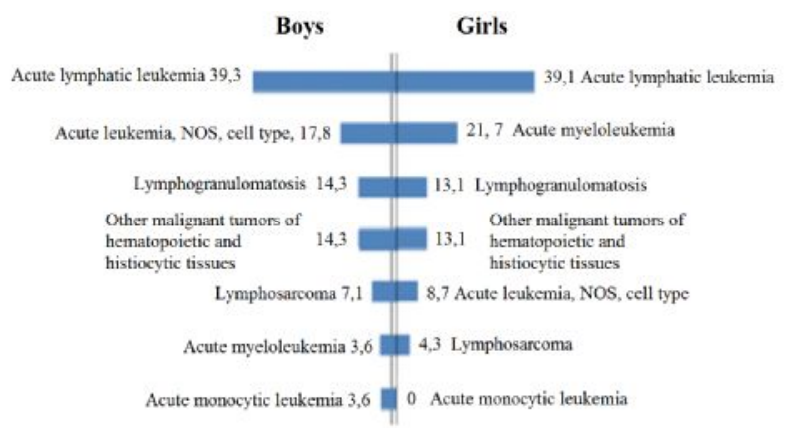

Fig.2. Leukemia ranking by $\operatorname{sex}(\%)$

nance in children. For boys, this pathology was diagnosed in $3.6 \%$ of cases, in girls - not a single case was revealed.

The mean age for hemoblastosis occurrence made 6 years old with no distinction of sex. The data on the structure of children's Leukemia as a whole and for each sex separately do not differ from the national and global statistics [6, 23].

Parents of children in both groups were exposed to a wide range of doses. Table 2 shows doses characteristics of external gamma radiation on gonad prior to conception.

Table 2

Characteristic of external gamma radiation on gonad

\begin{tabular}{|c|c|c|c|c|}
\hline \multirow{2}{*}{ Doses of external gamma radiation on gonad } & \multicolumn{2}{|c|}{$\begin{array}{l}\text { Irradiated parents } \\
\text { in "cases" group }\end{array}$} & \multicolumn{2}{|c|}{$\begin{array}{l}\text { Irradiated parents } \\
\text { in "controls" group }\end{array}$} \\
\hline & Fathers & Mothers & Fathers & Mothers \\
\hline $\begin{array}{l}\text { Average dose of external gamma radiation on } \\
\text { gonads, } \mathrm{mGy} *\end{array}$ & $\begin{array}{c}476.4 \\
(21.3-3397.3)\end{array}$ & $\begin{array}{c}353.9 \\
(2.1-999.9)\end{array}$ & $\begin{array}{c}441.6 \\
(0.5-2899.3)\end{array}$ & $\begin{array}{c}376.7 \\
(2.1-1190.2)\end{array}$ \\
\hline $\begin{array}{l}\text { Median dose of external gamma radiation on } \\
\text { gonads, } \mathrm{mGy} * *\end{array}$ & $\begin{array}{c}149.5 \\
(50.3-192.5)\end{array}$ & $\begin{array}{c}60.0 \\
(2.1-999.9)\end{array}$ & $\begin{array}{c}167.0 \\
(35.8-342.8)\end{array}$ & $\begin{array}{c}206.9 \\
(63.2-593.9)\end{array}$ \\
\hline
\end{tabular}

*- doses range given in brackets

**_ interquartile range given in brackets

Table 3

Odds ratios calculations

\begin{tabular}{|c|c|c|c|c|c|c|c|c|c|}
\hline \multirow{2}{*}{ Group } & \multicolumn{3}{|c|}{ Risk factor present } & \multicolumn{3}{|c|}{ No risk factor } & \multicolumn{3}{|c|}{ OR $(95 \% \mathrm{CI})$} \\
\hline & Total & Boys & Girls & Total & Boys & Girls & Total & Boys & Girls \\
\hline $\begin{array}{l}\text { Outcome } \\
\text { present } \\
(\mathrm{n}=51)\end{array}$ & 15 & 7 & 8 & 36 & 21 & 15 & \multirow{2}{*}{$\begin{array}{c}0.55(0.28- \\
1.07)\end{array}$} & \multirow{2}{*}{$\begin{array}{c}0.48 \\
(0.19- \\
1.22)\end{array}$} & \multirow{2}{*}{$\begin{array}{c}0.64(0.25 \\
1.65)\end{array}$} \\
\hline $\begin{array}{l}\text { No out- } \\
\text { come } \\
(n=197)\end{array}$ & 85 & 44 & 41 & 112 & 63 & 49 & & & \\
\hline
\end{tabular}


The external gamma radiation accumulated doses on gonads among parents of children with hematological malignancies ranged from 2.1 to $3397.3 \mathrm{mGy}$, among the parents in the group of "controls": from 0.5 to 2899.3 mGy. Median pre-conceptive gonadal dose of external gamma radiation in the parents of children with hematological malignancies was lower than that of parents in the "controls" group. Thus, among the "cases" group mothers, the median dose was $60.0 \mathrm{mGy}$, whereas in the controls: $206.9 \mathrm{mGy}$; among the fathers of the "cases" group, the median dose reached $149.5 \mathrm{mGy}$, in the "controls" group: 167.0 mGy.

Among parents of children with hematological malignancies, the highest values of pre-conceptive doses of external gamma radiation on gonads up to $3397.3 \mathrm{mGy}$ were observed among radiochemical production workers. Among parents of children without oncohematological pathology, the highest doses (up to $2899.3 \mathrm{mGy}$ ) were typical for radiochemical and plutonium reprocessing staff.

The maximum values of external gamma radiation doses on gonads are registered at the beginning of the follow-up period (1949-1953), which corresponds to the highest doses of "Mayak" employees' occupational exposure in the early operational years due to shortcomings in the production process and personal protection methods.

To identify statistical relationship between the radiation risk factor effect on the workers and the outcome in the form of Leukemia in their descendants, odds ratio index was calculated. The results are shown in Table 3.

OR value in the two groups compared without distinction by gender showed no significant statistical relationship between preconceptive exposure of parents and hematological malignancies in their descendants: OR $0.55(0.28-1.07)$. OR result in boys of 0.48 (0.19-1.22) and girls: 0.64 (0.25-1.65) also serves as a basis for the null hypothesis of no relationship between the risk factor of parent exposure prior to conception, and the outcome in offspring in the form of hemoblastosis.
According to the national and global statistics, onco-hematological pathology occurs more often in boys [8,23]. However, in our study, the risk of hematological malignancies in the offspring of the exposed parents of girls was slightly higher than that of boys. We interpret these data with caution because of the small number of cases observed (8 girls and 7 boys with hematological malignancies of irradiated parents) that requires continuous monitoring over the descendants of radiationhazardous production workers.

Thus, our retrospective epidemiological study with a "nested case-control approach", covering the 60-year follow-up of the descendants of PE "Mayak" staff, revealed no significant causal relationship of preconceptive prolonged external gamma radiation of "Mayak" workers and oncohematological pathology in their children. The link with internal exposure was out of the present study.

A number of epidemiological studies do not support association between the exposure to ionizing radiation on gonads and the development of cancer and other genetic diseases in offspring $[4,12,13]$. Perhaps, this is due to existence of natural repair mechanisms that weaken harmful external agents, including ionizing radiation. However, molecular genetic studies indicate high probability of undesirable mutations in the offspring of persons exposed to prolonged irradiation. Radiation-induced chromosomal instability in somatic cells is considered as oncogenic factor [2]. Polyetiology of neoplastic process and a variety of nonradiation carcinogenic factors greatly complicate choosing the determinant cause for tumor appearance.

The absence of causal relationship between parent irradiation and hemoblastosis in their offspring under the age of 15 that we've identified does not preclude their predisposition to neoplasms and probability of carcinogenic effect in the older age, as well as process onset in the form of solid cancer. In this connection, it's necessary to continue monitoring the children of workers exposed to ionizing 
radiation sources to identify the long-term effects of exposure.

\section{Conclusions:}

1. Hemoblastosis structure in a cohort of children population of Ozyorsk for the period 1949-2009 is consistent with national statistics. Acute leukemia was a major contributor to the structure of malignant tumors of hematopoietic and lymphoid tissues (66.7\% of all cases).
2. No effects of prolonged preconceptive external gamma-irradiation of parents gonads on the occurrence of hematological malignancies in the offspring by "nested case-control" study revealed: OR 0.55 (0.281.07).

3. For final conclusions on the presence of carcinogenic risk in offspring, the follow-up is to be continued, including analysis within a cohort study and the study of doseeffect relationship.

\section{References}

1. Vasilenko E.K. Dozimetriia vneshnego oblucheniia rbotnikov PO «Maiak»: pribory, metody, rezul'taty [Dosimetry of external radiation in IG "Mayak" workers: instruments, methods, results]. Istochniki i effekty oblucheniia rabotnikov PO «Maiak» i naseleniia, prozhivaiushchego v zone vliianiia predpriiatiia [The sources and the effects of exposure of IG "Mayak" workers and the population living in the zone of the enterprise influence]. In: M.F. Kiseleva, S.A. Romanova ed. Chelyabinsk: Cheliabinskii dom pechati Publ., 2009, Part 1, pp. 51-100 (in Russian).

2. Demina E.A., Pilipchuk E.P. Komutageny i risk razvitiia radiogennogo raka [Comutagenes and risk of radiogenic cancer]. Zlokachestvennye opukholi, 2013, vol. 2, no.6, pp. 133-188 (in Russian).

3. Domninskii D.A. Molekuliarnye mekhanizmy leikozogeneza. Gemoblastozy limfoidnogo proiskhozhdeniia (lektsiia 4) [Molecular mechanisms of leukaemogenesis. Lymphoid hematological malignancies]. Onkogematologiia, 2011, vol. 4, pp. 39-50 (in Russian).

4. Koterov A.N., Biriukov A.P. Deti uchastnikov likvidatsii posledstvii avarii na Chernobyl'skoi atomnoi elektrostantsii. Soobshchenie 2. Chastota otklonenii i patologii i ikh sviaz' s neradiatsionnymi faktorami [The Offspring of Liquidators of Chernobyl Atomic Power Station Accident 2. The Frequency of Anomalies and Pathologies and its Connection to Non-Radiation Factors]. Meditsinskaia radiologiia $i$ radiatsionnaia bezopasnost', 2012, vol. 57, no. 2, pp. 51-77 (in Russian).

5. Men' T.Kh., Rykov M.Iu., Poliakov V.G. Zlokachestvennye novoobrazovaniia u detei v Rossii: osnovnye pokazateli i tendentsii [Malignancies in children in Russia: trends and highlights]. Rossiiskii onkologicheskii zhurnal, 2015, vol. 20, no. 2, pp. 43-47 (in Russian).

6. Bezlepkin V.G., Kirillova E.N., Zakharova M.L., Pavlova O.S., Lomaeva M.G., Fomenko L.G., Antipova V.N., Gaziev A.N. Otdalennye i transgeneratsionnye molekuliarno - geneticheskie effekty prolongirovannogo vozdeistviia ioniziruiushchei radiatsii u rabotnikov predpriiatiia iadernoi promyshlennosti [Long-term and transgenerational molecular - genetic effects of prolonged exposure to ionizing radiation in nuclear industry employees]. Radiatsionnaia biologiia. Radioekologiia, 2011, vol. 51. no. 1, pp. 20-32 (in Russian).

7. Petrushkina N.P., Koshurnikova N.A., Kabirova N.R., Okatenko P.V. Otsenka radiatsionnogo riska dlia naseleniia, prozhivaiushchego vblizi predpriiatiia atomnoi promyshlennosti. Soobshchenie 1. Metodicheskie podkhody k otsenkam radiatsionnogo riska. Sostav Detskogo Registra [Radiation Risk Assessment for Communities Living Near the Atomic Plants. Report 1. Procedures of radiation risk assessments. Child's Register]. Voprosy radiatsionnoi bezopasnosti, 1996, vol. 2, pp. $46-50$ (in Russian).

8. Tel'nov V.I., Kabirova N.R., Okatenko P.V. Sinergizm prekontseptivnogo oblucheniia i roditel'skoi onkopatologii v povyshenii kantserogennogo riska u potomkov professional'nykh rabotnikov [Synergism of preconceptive radiation exposure and parents' onco-pathology in the rise of carcinogenic risk in the offsprings of professional employees]. Gigiena $i$ sanitaria, 2015, vol. 94, no. 7, pp. 110-114 (in Russian).

9. Koshurnikova N.A., Shil'nikova N.S., Okatenko P.V. i dr. Kharakteristika kogort rabotnikov atomnogo predpriiatiia PO «Maiak» (chast' II) [Description of the Cohort of the Nuclear Industry Enterprise «Mayak» PA (Part II)]. Voprosy radiatsionnoi bezopasnosti, 1998, vol. 3, pp. 48-58 (in Russian). 
10. Baleva L.S., Nomura T., Sipiagina A.E., Karakhan N.M., Iakusheva E.N., Egorova N.I. Tsitogeneticheskie effekty i vozmozhnosti ikh transgeneratsionnoi peredachi $\mathrm{v}$ pokoleniiakh lits, prozhivaiushchikh $\mathrm{v}$ regionakh radionuklidnogo zagriazneniia posle avarii na Chernobyl'skoi AES [Cytogenetic effects and possibilities of their transgenerational transfer in the generations of persons living in radionuclide polluted areas after the Chernobyl accident]. Rossiiskii vestnik perinatologii $i$ pediatrii, 2016, vol. 3, pp. 87-94 (in Russian).

11. Milne E., Greenop K.R., Fritschi L., Attia J., Bailey H.D., Scott R.J., Ashton L.J., Smibert E., Armstrong B.K. Childhood and parental diagnostic radiological procedures and risk of childhood brain tumors. Cancer causes \& control, 2014, vol. 25, no. 3, pp. 375-383.

12. Johnson K.J., Alexander B.H., Doody M.M., Sigurdson A.J., Linet M.S., Spector L.G., Hoffbeck W.., Simon S.L., Weinstock R.M., Ross J.A. Childhood cancer in the offspring born in 1921-1984 to US radiologic technologists. Br. J. Cancer, 2008, vol. 99, no. 3, pp. 545-550.

13. Draper G. Preconception exposures to potential germ-cell mutagens. Radiat. Prot. Dosimetry, 2008, vol. 132, no. 2, pp. 241-245.

14. Puumala S.E., Ross J.A., Aplenc R., Spector L.G. Epidemiology of childhood acute myeloid leukemia. Pediatr. Blood Cancer, 2013, vol. 60, no. 5, pp. 728-733.

15. Kennedy A.E., Kamdar K.Y., Lupo P.J., Okcu M.F., Scheurer M.E., Dorak M.T. Genetic markers in a multi-ethnic sample for childhood acute lymphoblastic leukemia risk. Leuk. Lymphoma, 2015, vol. 56, no. 1, pp. 169-174.

16. Janiak M.K. Epidemiological evidence of childhood leukaemia around nuclear power plants. Dose Response, 2014, vol. 12, no. 3, pp. 349-364.

17. Kuehni C., Spycher B.D. Nuclear power plants and childhood leukaemia: lessons from the past and future directions. Swiss Med. Wkly, 2014, vol. 2, pp. 144.

18. Khokhryakov V.V., Khokhryakov V.F., Suslova K.G., Vostrotin V.V., Vvedensky V.E., Sokolova A.B., Krahenbuhl M.P., Birchall A., Miller S.C., Schadilov A.E., Ephimov A.V. Mayak Worker Dosimetry System 2008 (MWDS-2008): assessment of internal dose from measurement results of plutonium activity in urine. Health Phys., 2013, vol. 104, no. 4, pp. 366-378.

19. Chang J.S., Tsai C.R., Tsai Y.W., Wiemels J.L. Medically diagnosed infections and risk of childhood leukaemia: a population-based case-control study. Int. J. Epidemiol., 2012, vol. 41, no. 4, pp. $1050-1059$.

20. Kodaira M., Ryo H., Kamada N., Furukawa K., Takahashi N., Nakajima H., Nomura T., Nakamura N. No evidence of increased mutation rates at microsatellite loci in offspring of A-bomb survivors. Radiat. Res., 2010, vol. 173, no. 2, pp. 205-213.

21. Crump C., Sundquist J., Sieh W., Winkleby M.A., Sundquist K. Perinatal and familial risk factors for acute lymphoblastic leukemia in a Swedish national cohort. Cancer, 2015, vol. 121, no. 7, pp. $1040-1047$.

22. Tabrizi M.M., Hosseini S.A. Role of Electromagnetic Field Exposure in Childhood Acute LymphoblasticLeukemia and No Impact of Urinary Alpha- Amylase - a Case Control Study in Tehran, Iran. Asian Pac. J. Cancer Prev., 2015, vol. 16, no. 17, pp. 7613-7618.

23. Metayer C., Milne E., Clavel J., Infante-Rivard C., Petridou E., Taylor M., Schüz J., Spector L.G., Dockerty J.D., Magnani C., Pombo-de-Oliveira M.S., Sinnett D., Murphy M., Roman E., Monge P., Ezzat S., Mueller B.A., Scheurer M.E., Armstrong B.K., Birch J., Kaatsch P., Koifman S., Lightfoot T., Bhatti P., Bondy M.L., Rudant J., O'Neill K., Miligi L., Dessypris N., Kang A.Y., Buffler P.A. The Childhood Leukemia International Consortium. Cancer Epidemiol., 2013, vol. 37, no. 3, pp. 336-347.

Sosnina S.F., Kabirova N.R., Sokolnikov M.E., Okatenko P.V. Hemoblastoses in offspring of radiation-hazardous industries workers. Health Risk Analysis, 2016, no. 4, pp. 20-26. DOI: 10.21668/health.risk/2016.4.03.eng

Received: 06.09.2016

Accepted: 10.12 .2016

Published: 30.12.2016 